\title{
Readmission rates following heart failure: a scoping review of sex and gender based considerations
}

\author{
Amy Hoang-Kim', Camilla Parpia' ${ }^{1}$, Cassandra Freitas ${ }^{2}$, Peter C. Austinn ${ }^{3,4}$, Heather J. Ross ${ }^{2,5,6}$, \\ Harindra C. Wijeysundera ${ }^{3,4,5,7}$, Karen Tu ${ }^{5,8}$, Susanna Mak' ${ }^{5,9}$, Michael E. Farkouh ${ }^{2,5}$, Louise Y. Sun ${ }^{3,10,}$ \\ Michael J. Schull ${ }^{3,4,5,7}$, Robin Mason ${ }^{1}$, Douglas S. Lee Le $^{2,3,4,5,6^{*}}$ and Paula A. Rochon ${ }^{1,3,4,5}$
}

\begin{abstract}
Background: Although hospital readmission for heart failure (HF) is an issue for both men and women, little is known about differences in readmission rates by sex. Consequently, strategies to optimize readmission reduction programs and care strategies for women and men remain unclear. Our study aims were: (1) to identify studies examining readmission rates according to sex, and (2) to provide a qualitative overview of possible considerations for the impact of sex or gender.

Methods: We conducted a scoping review using the Arksey and O'Malley framework to include full text articles published between 2002 and 2017 drawn from multiple databases (MEDLINE, EMBASE), grey literature (i.e. National Technical information, Duck Duck Go), and expert consultation. Eligible articles included an index heart failure episode, readmission rates, and sex/gender-based analysis.

Results: The search generated 5887 articles, of which 746 underwent full abstract text consideration for eligibility. Of 164 eligible articles, 34 studies addressed the primary outcome, 103 studies considered sex differences as a secondary outcome and 25 studies stratified data for sex. Good inter-rater agreement was reached: 83\% title/ abstract; 88\% full text; kappa: 0.69 (95\%Cl: 0.53-0.85). Twelve of 34 studies reported higher heart failure readmission rates for men and six studies reported higher heart failure readmission rates for women. Using non composite endpoints, five studies reported higher HF readmission rates for men compared to three studies reporting higher HF readmission rates for women. Overall, there was heterogeneity between studies when examined by sex, but one observation emerged that was related to the timing of readmissions. Readmission rates for men were higher when follow-up duration was longer than 1 year. Women were more likely to experience higher readmission rates than men when time to event was less than 1 year.

Conclusions: Future studies should consider different time horizons in their designs and avoid the use of composite measures, such as readmission rates combined with mortality, which are highly skewed by sex. Cointerventions and targeted post-discharge approaches with attention to sex would be of benefit to the HF patient population.
\end{abstract}

\footnotetext{
* Correspondence: douglas.lee@ices.on.ca

${ }^{2}$ Peter Munk Cardiac Centre of University Health Network, Toronto, Canada

${ }^{3}$ ICES, Toronto, Canada

Full list of author information is available at the end of the article
}

(c) The Author(s). 2020 Open Access This article is licensed under a Creative Commons Attribution 4.0 International License, which permits use, sharing, adaptation, distribution and reproduction in any medium or format, as long as you give appropriate credit to the original author(s) and the source, provide a link to the Creative Commons licence, and indicate if changes were made. The images or other third party material in this article are included in the article's Creative Commons licence, unless indicated otherwise in a credit line to the material. If material is not included in the article's Creative Commons licence and your intended use is not permitted by statutory regulation or exceeds the permitted use, you will need to obtain permission directly from the copyright holder. To view a copy of this licence, visit http://creativecommons.org/licenses/by/4.0/ The Creative Commons Public Domain Dedication waiver (http://creativecommons.org/publicdomain/zero/1.0/) applies to the data made available in this article, unless otherwise stated in a credit line to the data. 


\section{Brief summary}

There has been increased attention on reducing hospital readmission rates. In this scoping review, we found notable variation exists in studies with sex stratified analyses for HF patients readmitted to hospital. Few studies were prospective in design, and results could be conflated by reporting of composite measures and time to event. Co-interventions and targeted post-discharge approaches need to be revisited for men and women.

\section{Background}

The rise in hospital readmissions is a global concern, placing considerable burden on patients, treatment costs, and hospital resources [1]. In the United States, the 30-day readmission rate for those with heart failure (HF) increased from 17 to $20 \%$ between the years 1993 and 2006 [2]. The number of people living with HF is increasing, and age/sex-standardized prevalence of the condition has been relatively stable over time [3]. Current patterns of hospital readmission are often associated with organizational factors, such as a length of stay, and clinical factors, such as age and comorbidities [4]. Improved quality of care at patient intake is also associated with a lower probability of readmission [5, 6]. Strategies to reduce readmission rates have shifted from hospitalbased to more patient-centred strategies, such as telemonitoring, which may benefit patients by facilitating their access to health care services $[7,8]$. Public reporting and financial incentives have been trialed by governments with the intent to reduce hospitalization rates $[9,10]$.

Heart failure is a growing problem with similar prevalence in men and women [11-13]. However, information on processes, quality of care, health status outcomes, or other patient care experiences has not been explored in the context of sex and gender. Heart failure with preserved ejection fraction (HFpEF) is more prevalent in women [13]. The lifetime risk of heart failure is $15 \%$ for women and $11 \%$ for men for those without a history of myocardial infarction at age 40 [8]. A few authors have focused on sex differences in heart failure [14-17] but no study to date has examined this in relation to readmission rates. This article draws on a scoping review protocol to better understand current patterns of readmission and the interpretation of observed patterns in relation to sex. Our aim was to examine studies reporting a higher heart failure readmission rate for either women or men, and to provide a qualitative overview of the possible considerations for the impact of sex and gender on this outcome.

\section{Methods}

\section{Study protocol}

A scoping review protocol was developed using the methodological framework proposed by Arksey and O'Malley [18]. In addition to the aforementioned methods, we also used the Joanna Briggs Institute Methodology for scoping reviews [19] and further refined the process using recommendations put forth by Levac et al. [20] This scoping review is related to the COACH trial (clinicaltrials.gov NCT02674438Last accessed October 2, 2017). A consultation of experts was included to inform the search for additional articles of interest.

\section{Information sources and literature search}

The search strategy was developed in consultation with the research team and was peer-reviewed by an expert librarian using the PRESS peer-review of electronic search strategy checklist [21] (Appendix). Multiple databases were searched, from 2002 up to May 29, 2017, including MEDLINE, EMBASE, PubMed, CINAHL, and Web of Science. Experts were then consulted up until October 16, 2017 for additional articles of interest (Table 1). Keywords and combinations of mesh terms were used to narrow the search strategy: "heart failure" OR "systolic dysfunction" OR "diastolic dysfunction" OR "heart ventricular failure" OR "left ventricular dysfunction" OR "cardiac failure" OR "cardiac decompensation" OR "heart decompensation" was combined with Readmission* or readmit* or rehospi$\mathrm{tal}^{*}$ and sex, gender or male/female. Additional filters narrowed the results to those papers published in the past 15 years and limited to humans. The database search was supplemented by a manual search of related references in the literature drawn from the Sex and Gender-Specific Medicine (SGSM) PubMed database (Texas Tech University).

\section{Eligibility criteria}

We included reports, both published and unpublished, that were primary research and in English. Further consideration for inclusion was whether the results disaggregated for sex or gender in readmission. Articles were excluded if they did not include HF as a first episode, enrolled exclusively a pediatric population (or those less than 18 years of age), was not full text, or published more than 15 years prior to the time the search was performed.

\section{Study selection process}

The screening criteria were established a priori and calibrated amongst the team (DSL, RM, PR, AHK, $\mathrm{CP})$ with a pilot-test by screening title and abstract on a random sample of 220 articles and 100 full text 
Table 1 Study characteristics

\begin{tabular}{|c|c|}
\hline Study Characteristics & Type, $n$ \\
\hline Journal disciplines & $\begin{array}{l}\text { Peer-reviewed or double blind, } \\
n=34 \text { Dissertations, } n=2\end{array}$ \\
\hline \multirow[t]{16}{*}{$\begin{array}{l}\text { Grey Literature }(n=\text { included/ } \\
\text { potentially eligible) }\end{array}$} & $\begin{array}{l}\text { CADTH-Canadian Agency for } \\
\text { Drugs and Technologies in } \\
\text { Health } n=0 / 15\end{array}$ \\
\hline & Center for Disease Control n.r. \\
\hline & $\mathrm{ClH}$ n.r. \\
\hline & Health Canada $n=0 / 9$ \\
\hline & Google Scholar $n=1 / 491$ \\
\hline & TRIP $n=1 / 19$ \\
\hline & $\begin{array}{l}\text { National Technical Information } \\
\text { Service } n=1 / 581\end{array}$ \\
\hline & Scopus $n=1 / 10$ \\
\hline & Duck Duck Go n = 2/200 \\
\hline & $\begin{array}{l}\text { UofT Theses and Dissertations in } \\
\text { the Sciences } n=0\end{array}$ \\
\hline & OAlster $n=0 / 2$ \\
\hline & Health Quality Ontario, $n=0 / 5$ \\
\hline & $\begin{array}{l}\text { New York Academy of Medicine's } \\
\text { Grey Literature Report } n=0\end{array}$ \\
\hline & Open Grey n=0/4 \\
\hline & T-space $n=0 / 31$ \\
\hline & World Health Organization n.r. \\
\hline Consultation Experts & $\begin{array}{l}\text { Journal Articles } 1 / 7 \text { (exclusion } \\
\text { criteria: did not address re-admission) }\end{array}$ \\
\hline \multirow[t]{2}{*}{ Study Design } & Prospective $n=11$ \\
\hline & Retrospective $n=25$ \\
\hline \multirow[t]{3}{*}{ Year of publication } & $2013-2017 n=14$ \\
\hline & $2008-2012 n=13$ \\
\hline & $2002-2007 n=9$ \\
\hline \multirow[t]{5}{*}{ Geographical region } & $\begin{array}{l}\text { North America (US } n=14, \\
\text { Canada } n=4 \text { ) }\end{array}$ \\
\hline & Europe $n=11$ \\
\hline & Asia $n=4$ \\
\hline & Australia $n=2$ \\
\hline & Africa $n=1$ \\
\hline
\end{tabular}

${ }^{\mathrm{a} N . r .}$ Not reported

articles. After an acceptable inter-rater agreement was established at $80 \%$, pairs of reviewers (CP, AHK) screened the pool of potentially eligible articles.

\section{Data items and data abstraction process}

We employed a 'descriptive-analytical' method, a narrative study design, which applies a common framework to all the included studies [20]. A sample of articles was read, and a data abstraction chart was developed. Charting is a technique for synthesizing and interpreting qualitative data by sifting and sorting materials by key issues and themes [19, 22]. We charted data into categories of study design, objectives (primary, other), study population, setting, sample estimation, endpoints, and statistical methods for sex group differences. Charting was stratified by sex for sample size, age, sample lost to follow up, event-free survival, mortality rate, all-cause and heart failure readmission rates, non-cardiovascular readmission rates, and any other potentially important findings. Length of hospital stay, time to event, and hazard ratios for readmission were also extracted. The chart was calibrated by the team (WW, RM, PR, DL, AHK, CP) on a sample of 12 included articles (11 from the sex and gender-specific medicine PubMed database and 1 article from the grey literature). Two reviewers used a standard form to decide which resources contained a primary objective evaluating sex differences in patients with heart failure following readmission.

When more than one outcome was reported in an article, we used a hierarchical selection process: (a) authors' explicit declaration of primary objective, (b) the outcome used to calculate the sample size, (c) authors' attribution of importance to the outcome in their description of the results, or (d) the outcome that appeared first in the methods section [23]. We used the category "Other" to classify resources that looked at patient populations presenting with a first episode of heart failure, if sex differences following readmission was specified as a secondary outcome measure or other (Fig. 1). Since studies with composite outcomes can mask associations that might be directionally opposite for death versus readmission, we determined whether composite outcomes were used in combination with mortality. We used the category "Background" to classify resources that contained information about readmission rates for men and women, but the authors did not perform sex-stratified analyses. Disagreements were resolved by discussion and other authors were involved to assist with ambiguous cases.

\section{Definition of sex and gender}

Although the number of publications that are relevant to sex/gender in the field of HF has grown over the years (Table 1), we found that there is still much confusion over terminology. For consistency, in this review "sex" will refer to a set of biological attributes in human participants that are associated with physical and physiological features [24]. The term "gender" will refer to socially constructed roles, relationships, behaviours, and powers as defined by the Government of Canada [24]. However, the data charted are reported per verbatim as used by the authors of the full text resources. 


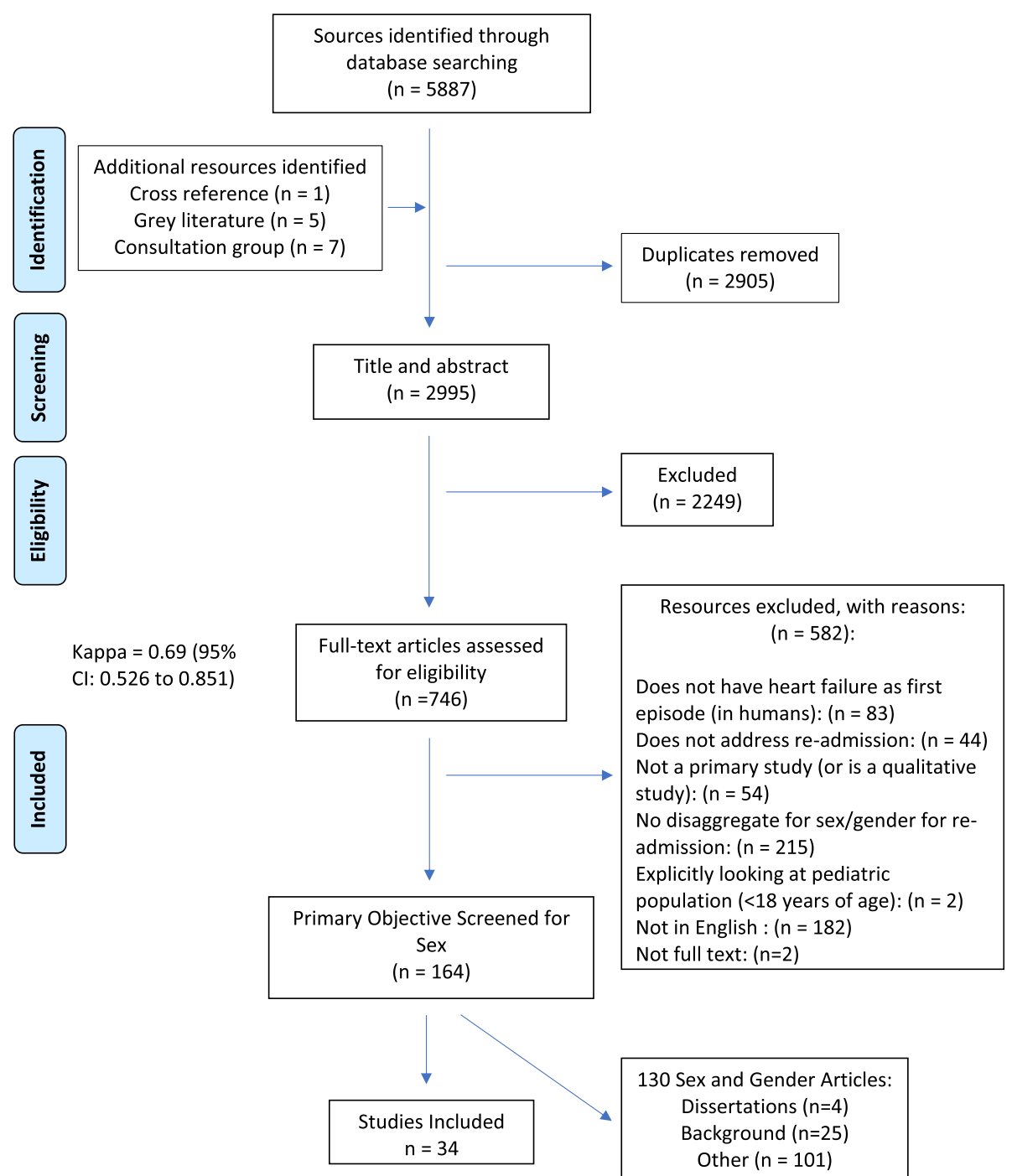

Fig. 1 Prisma flow diagram showing the process used for screening studies using sex-gender analysis for HF readmissions

\section{Results}

\section{Article types}

The electronic database search generated 5887 resources. Six additional potential records were identified by a hand search of references from the included articles, the grey literature, and by consulting a group of experts in the field. After duplicates were removed and resources were screened for eligibility, 36 sources remained, comprising 34 journal articles and 2 dissertations (Fig. 1). Good inter-rater agreement for a pair of reviewers was reached at each stage of the eligibility assessment (83\% title/abstract; $88 \%$ full text; kappa $=0.69$ [95\% CI: 0.53-0.85]). Most of the sources were recently published: 14 (20132017), 13 (2008-2012) and 9 (2002-2007) (Table 1). Twenty-five of the studies were retrospective and 11 were prospective in study design. Most of the studies were from North America including four from Canada. One hundred three sources were classified as "Other" and 25 sources were considered "Background".

\section{Clinical aims}

A broad range of research questions was addressed. Twenty-one study objectives (34\%) focused on predictors, risk or prognostic factors, 15 (24\%) presented a query into the clinical profiles or etiology of patients readmitted with an index diagnosis of heart failure. Sex differences were explicitly stated only in 12 (19\% study objectives). Environmental or external factors such as timing or setting were the least frequently addressed [objectives: 1 (2\%) and $2(3 \%)$, respectively. 


\section{Definition of heart failure}

Notably for defining heart failure, none of the included studies considered sex differences in HF presentation or sex-specific characteristics. A large proportion of studies in this scoping review defined HF using the World Health Organization's International Classification of Diseases code: $14(35 \%)$ studies. The remaining $6(16 \%)$ studies used the Framingham study clinical criteria, 4 (11\%) studies, adopted the criteria defined by the European Society of Cardiology, 7 (18\%) papers defined HF with clinical examinations, 3 (7\%) studies, used specific regional hospital admission codes or registry database codes, in $1(2 \%)$ study, HF was defined as impaired cardiac output, and in 3 (7\%) studies, HF was not defined. In addition, $4(10 \%)$ studies reported using multiple diagnostic criteria. HF definitions are summarized in Table 2.

\section{Outcomes reported}

Some studies reported readmission outcomes separately while others examined the composite of death or readmission to hospital. Six studies reported that women had higher rates of readmission or experienced the composite outcome more frequently than men (Table 3). Among these 6 studies, 4 had a mean follow-up duration of 3 months or less. Amongst studies in which non-composite outcomes were used, we found 3 that reported higher heart failure readmission rates in women when compared to men $[25,26,38]$ (Table 4). One study reported cardiovascular event-free survival (as defined by survival free from HF admission, acute myocardial infarction, coronary revascularization, valvular surgery, or heart transplantation) and found significantly lower risk in women [38].

Twelve studies reported higher readmission or composite outcomes in men. Among these, 6 studies demonstrated higher all-cause readmission rates [27, 29, 30, 40, 53, 58] (Table 5) and 4 studies reported higher hazard ratios for composite events [28, 31, 39, 50] (Table 6). In a prospective study, Nieminen et al. [53] reported men having higher rates of all-cause readmission at 1 year compared to a 3-month endpoint. In a Canadian retrospective study, Howlett et al. [28] reported that men were more likely to die than women following rehospitalization at 12 months using the composite measure of death and/or hospital readmission. In total, 5 of 12 studies finding higher readmission rates (not combined with other endpoints) in men examined follow-up durations of 12 months or more.

Eighteen studies reported no sex differences in readmission rates between men and women (Table 7).

\section{Non-HF cardiovascular causes of readmission}

The observed sex differences in readmission rates could be potentially explained by several factors including patient characteristics and differences in processes of care. Vader [46] reported risk factors for post-discharge readmission or death in patients treated for acute heart failure, including male sex, non-use of angiotensin-converting enzyme inhibitors (ACEI) or angiotensin receptor blockers (ARB), lower baseline sodium, non-white race, lower systolic blood pressure at discharge or day 7 , increased length of stay, and depression. In addition, both Vader [46] and Howie-Esquivel [42] reported a two-fold increase in cardiac readmission rates for women whose ethnicity was Caucasian. Older age and the comorbidities that are associated with aging were reported to be risk factors for readmission $[27,30]$. Comorbidities including myocardial infarction, chronic kidney disease, cancer, and diabetes mellitus were cited as predictors of increased readmission risk [27].

Some co-variates such as diabetes, valvular heart disease, blood pressure, and atrial fibrillation were sex-sensitive, and could potentially have a role in differential risk of readmissions in women and men. Diabetes and anemia were significantly more frequent in women [53]. Women more often presented with atrial arrhythmia and atrial fibrillation, and men with ventricular arrhythmias [53]. Women were more likely to present with valvular heart disease, hypertension, and preserved left ventricular function, but also less likely to be diabetic or smokers $[52,53]$. The presence of coronary disease and an ischemic etiology may modify HF outcomes in women and men. Specifically, Mullens [54] reported better survival rates for women with a nonischemic cause, whereas there was a trend toward worse survival in those with ischemic heart failure.

The effects of ejection fraction on sex-specific readmission rates are variable. Alla [49] reported that males had a relative risk of hospitalization for heart failure that was greater than females when the ejection fraction was reduced but not when preserved. The authors' survival analysis showed an advantage for females with $\mathrm{HF}$ and reduced ejection fraction [49]. In a retrospective study, Goncalves et al. [39] found that males with preserved and reduced left ventricular systolic function were more likely to die and/or be re-admitted within 6 months.

Howlett [28] found that women were more likely to receive usual care rather than specialized heart management from a clinic (52\% vs. 37\%). Nieminen [53] observed higher rates of readmission in men even when both sexes were treated as frequently and as long in the different types of wards (internal medicine, cardiology, 
Table 2 The primary author and year of publication, and heart failure as defined in the study

\begin{tabular}{ll}
\hline Primary Author (Year of Publication) & Definition of heart failure \\
\hline Macdonald (2008) [25]; Arora & World Health Organization's \\
(2017) [26]; Omersa (2016) [27]; & International Classification of \\
Howlett (2009) [28]; Madigan & Diseases code-10th revision; 9th \\
(2012) [29]; Robertson (2012) & revision; Australian modification
\end{tabular}

[307: Bradford (2016) [32]; Eastwood (2014) [33]; Sheppard (2005)

[34]; Chun (2012) [35]; Howlett (2009) [28]; Jenghua (2011) [36]; Lee (2004) [37]

Jimenez-Navarro (2010) [38]; Goncalves (2008) [39]; Ogah (2014) [40]; Opasich (2004) [41]

Howie-Esquivel (2007) [42]; Sato (2015) [43]; Ogah (2014) [40]; Ogah (2015) [44]; Sajeev (2017) [45]; Lee (2004) [37]

Vader (2016) [46]

Gevaert (2014) [47]

Chang (2014) [48]

Alla (2007) [49]

leva (2015) [50]

Tarantini (2002) [51]

Zsilinskza (2016) [52]

Sajeev (2017) [45]
European Society of Cardiology

Confirmed by a cardiologist, using standard Framingham criteria or exacerbation of a previously documented HF; Framingham criteria (including symptoms, physical examination, chest x-ray and echocardiographic findings)

The presence of more than one symptom (dyspnea, orthopnea, edema) and 1 sign (rales on auscultation, peripheral edema, ascites, or pulmonary vascular congestion on chest radiography) in DOSE-AHF or ROSE-HF or admission to the hospital with a primary diagnosis in CARRESS HF

Preserved left ventricular fraction was defined as left ventricular ejection fraction greater than or equal to $50 \%$ and heart failure with reduced ejection fraction was defined as less than 50\%

New onset of HF with acute decompensation or chronic HF with acute decompensation requiring hospitalization

Current or past evidence of low cardiac output or congestion edema, elevated jugular venous pressure, or rales or evidence of pulmonary congestion

Diagnostic Category - Nervous system, respiratory system, circulatory system, with HF-related events, from Agency for healthcare research and quality and centres for Medicare and medicaid services hierarchical condition category in hospital administrative database

Hospital admission for CHF

Heart Failure National Registry Emergency Module (ADHERE-EM) database

Chronic systolic HF was defined as systolic HF for at least 6 months with an
Table 2 The primary author and year of publication, and heart failure as defined in the study (Continued)

\begin{tabular}{ll}
\hline Primary Author (Year of Publication) & Definition of heart failure \\
\hline & EF of less than $50 \%$ and/or \\
& patients who are on standard \\
& HF medications, which \\
& include at least two groups \\
& of medications mentioned: \\
& ACEl/ARB, diuretics or digoxin \\
& Diastolic dysfunction was \\
& classified by the investigator \\
& as mild, moderate or severe \\
& according to echocardiographic \\
& criteria; signs of heart failure \\
& (rales, hypotension, hypoperfusion) \\
& and signs of heart failure on chest \\
& x-ray. Acute decompensated \\
& chronic heart failure was defined \\
& as worsening of heart failure in \\
& patients with a previous diagnosis \\
& or hospitalization for heart failure \\
& or as new-onset acute heart failure \\
& for patients with no prior history \\
& of heart failure
\end{tabular}

Mullens (2008) [54]

Impaired cardiac output (cardiac index $<2.4 \mathrm{Lmin} / \mathrm{m}^{2}$ )

Schwarz (2003) [55]; Otero-Ravina (2009) [56]; Ahmed (2014) [57]

Not reported; Diagnosis of HF made by a specialist (cardiologist and/or internist)

N.B. Does not include information from abstracts only or dissertations, unless linked to published article

intensive care unit and cardiac care unit). The initial place of presentation for both women and men was the emergency department followed by admission to the general ward [36].

There was some indication that whether women were alone, supported socially by a partner, or working could impact readmission rates. Niemminen [39] discussed that readmitted women were more often retired, living alone or in special accommodation.

\section{Differences in interventions}

Nieminen [39] described that women underwent significantly fewer invasive procedures. However, Chang [36] found no sex differences in the use of critical life-saving procedures such as renal replacement therapy, mechanical ventilation, defibrillation or cardiopulmonary resuscitation. Zsilinszka [44] also did not note any sex differences in use of dialysis or mechanical ventilation. It appeared that where differences in procedures were observed, there was some clinical discretion involved and they were not necessarily immediately critical for sustaining life. For example, invasive procedures such as coronary angiography were performed less often in women than men $(1.4 \%$ vs. $2.8 \%, p<0.001)$ [36]. Sheppard [32] also found that women underwent fewer non-invasive assessments of 


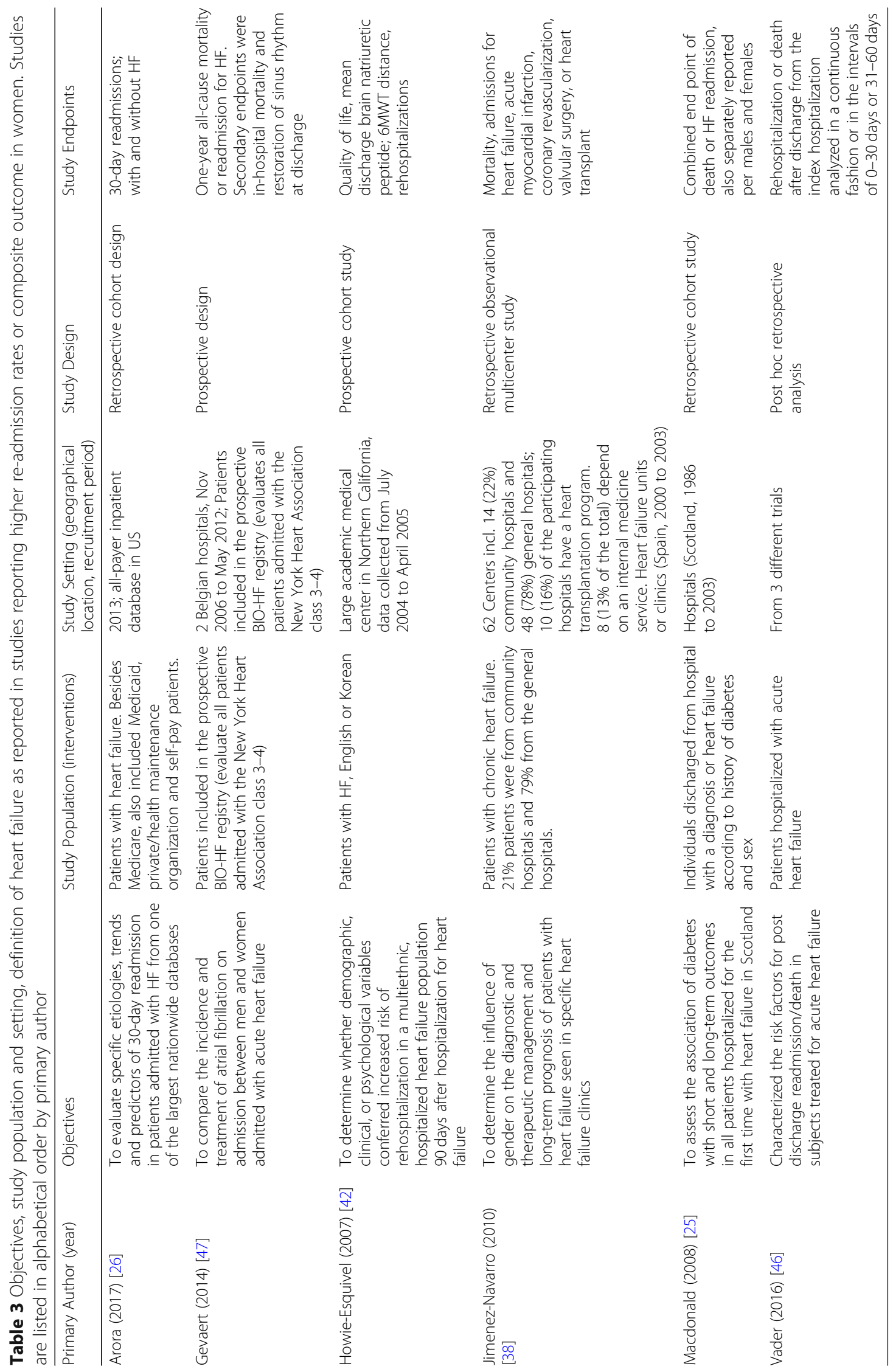




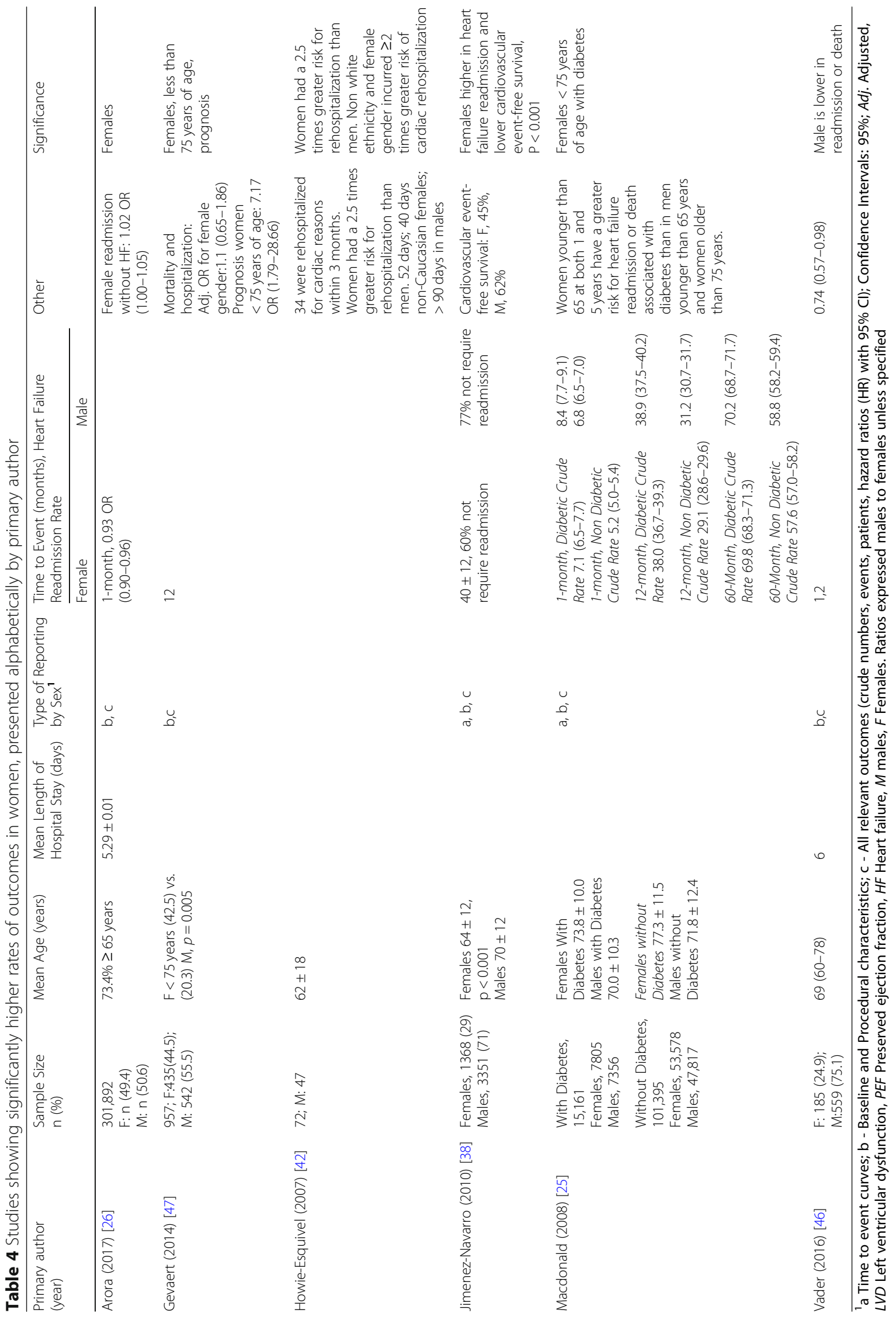




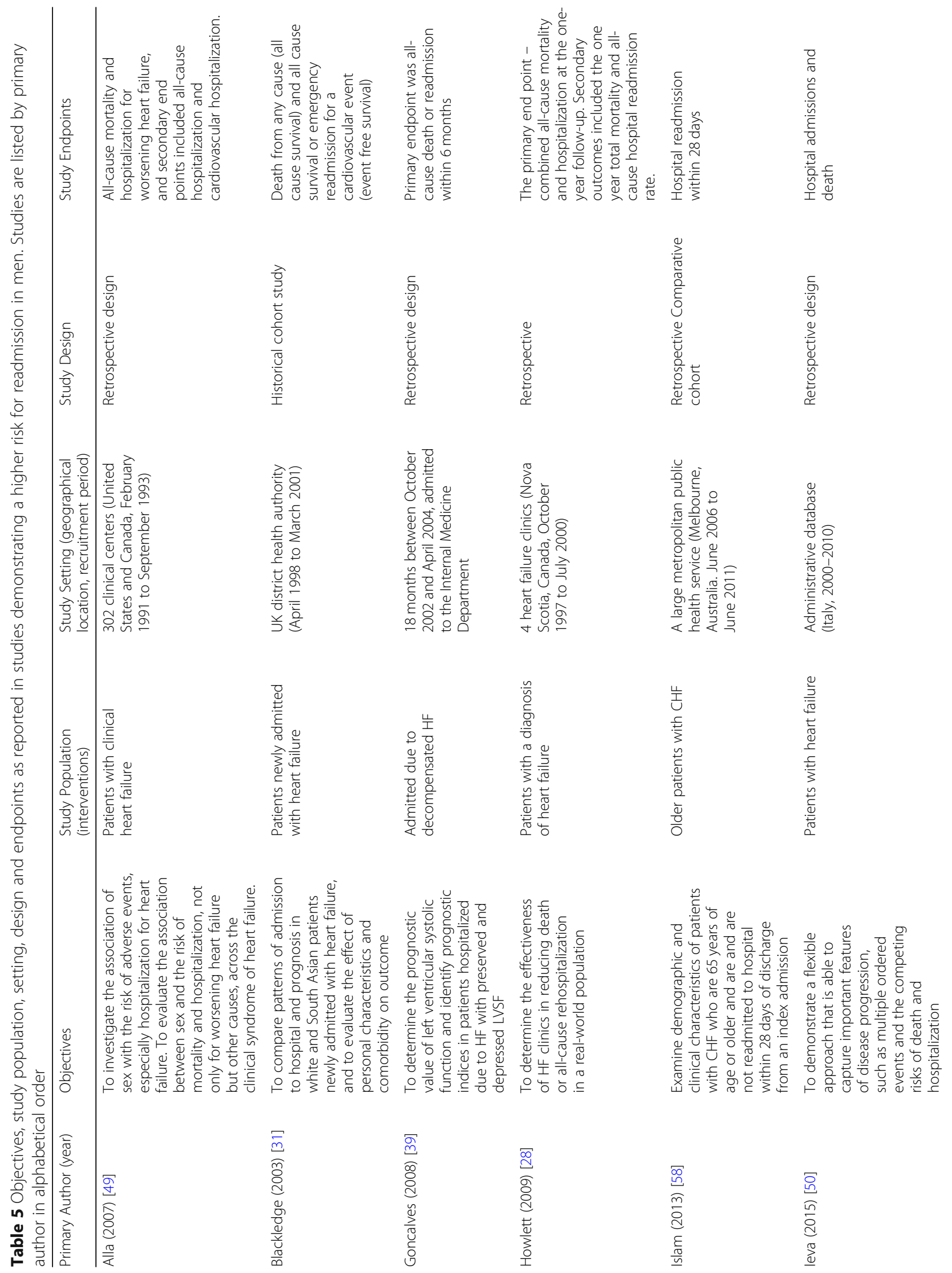




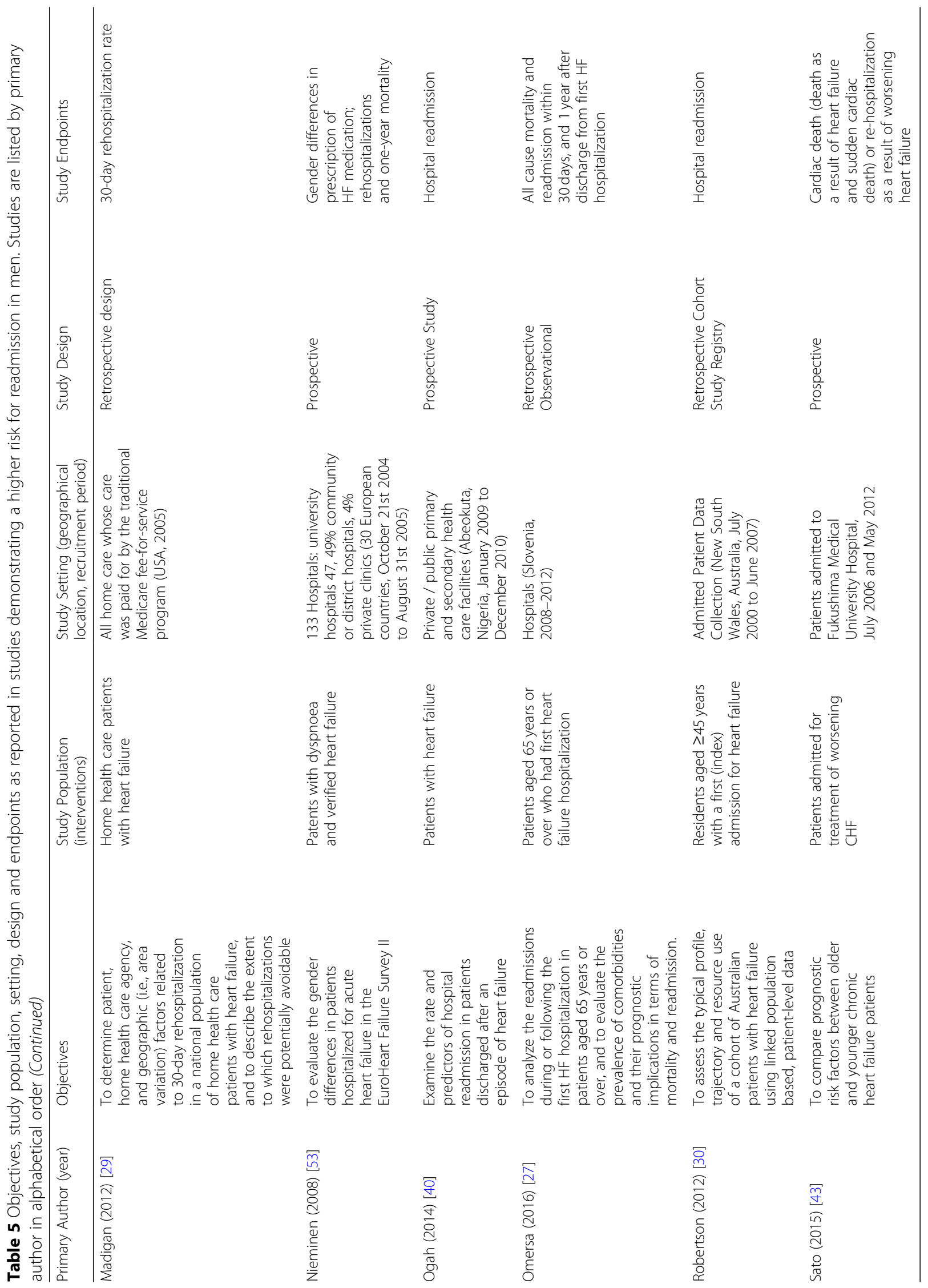




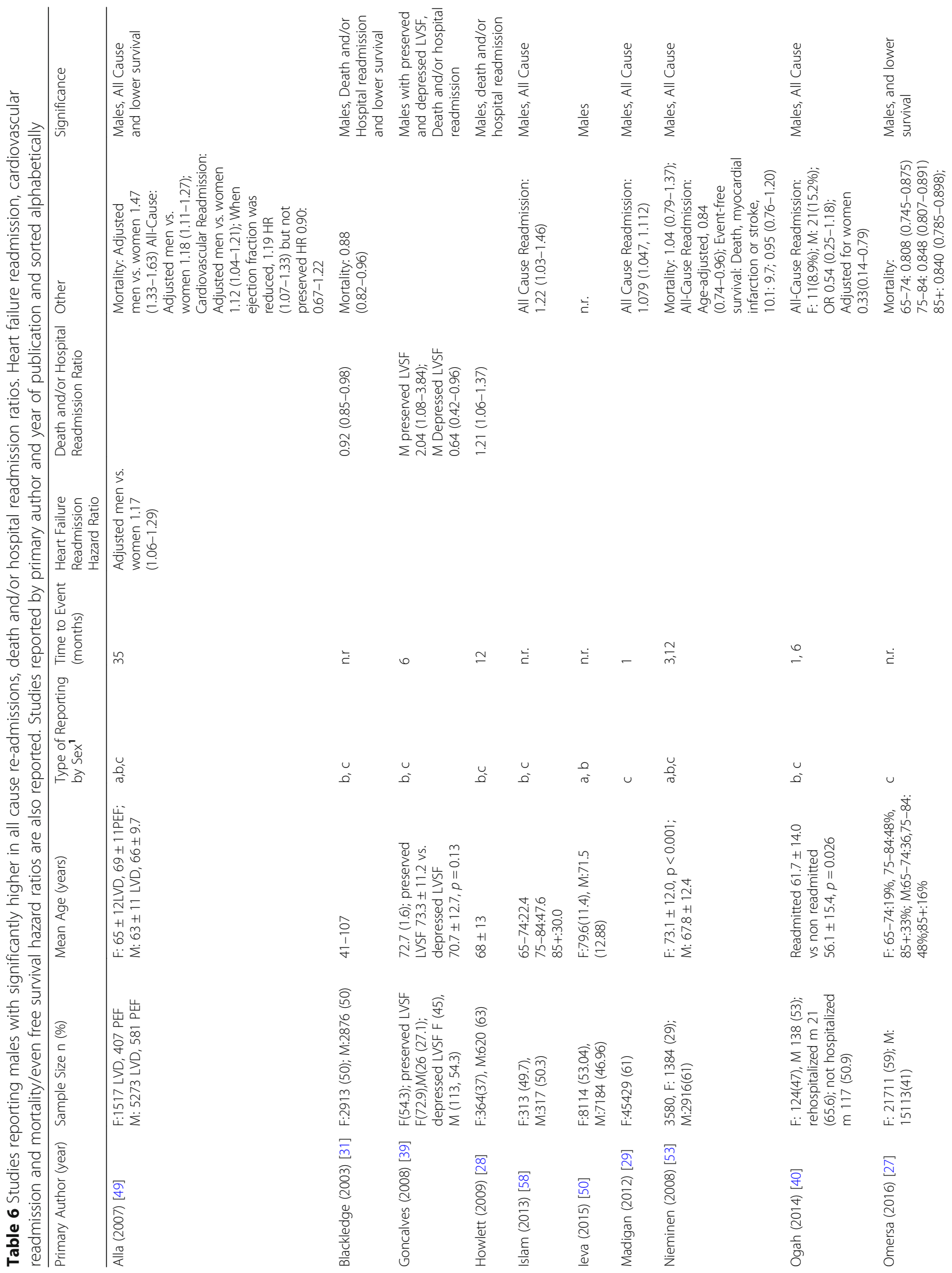




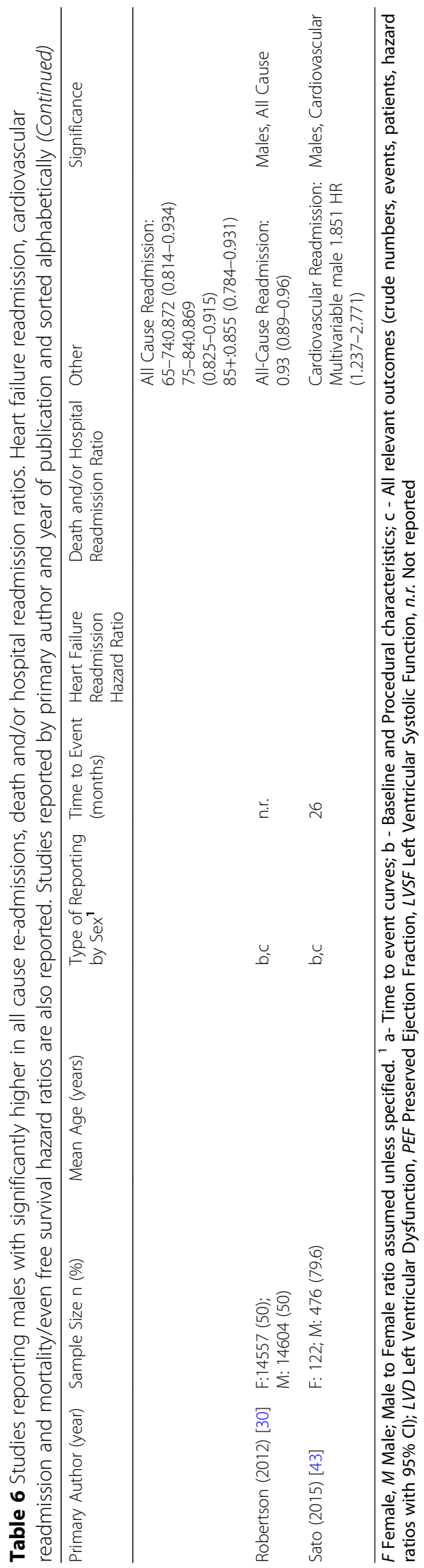


Table 7 Objectives, study population, setting, type of study, and study endpoints as reported in studies with similar rates between males and females. Studies reported by primary author in alphabetical order

\begin{tabular}{|c|c|c|c|c|}
\hline $\begin{array}{l}\text { Primary Author } \\
\text { (year) }\end{array}$ & Objectives & $\begin{array}{l}\text { Setting (geographical } \\
\text { location, recruitment period) }\end{array}$ & Study Design & Study Endpoints \\
\hline Ahmed (2014) [57] & $\begin{array}{l}\text { Examined the impact of } \\
\text { gender on a wide variety } \\
\text { of major natural history } \\
\text { endpoints in a propensity } \\
\text { matched population of } \\
\text { ambulatory chronic HF } \\
\text { patients in which men } \\
\text { and women were well } \\
\text { balanced on all measured } \\
\text { baseline covariates }\end{array}$ & $\begin{array}{l}302 \text { clinical centers across } \\
\text { the United States (186 } \\
\text { centers) and Canada } \\
\text { (116 centers) between } \\
\text { January } 1991 \text { and } \\
\text { August } 1993 .\end{array}$ & $\begin{array}{l}\text { Retrospective } \\
\text { observational }\end{array}$ & $\begin{array}{l}\text { Mortality, hospitalizations } \\
\text { (all cause, cardiovascular } \\
\text { causes and HF) }\end{array}$ \\
\hline Bradford (2016) [32] & $\begin{array}{l}\text { To evaluate the diagnosis } \\
\text { and timing and to identify } \\
\text { patient and clinical } \\
\text { characteristics associated } \\
\text { with } 30 \text { day readmissions } \\
\text { among heart failure patients. }\end{array}$ & $\begin{array}{l}\text { Acute care hospitals } \\
\text { (San Diego, US, October } \\
2009 \text { to November, 2014) }\end{array}$ & Retrospective & 30-day Readmissions \\
\hline Chang (2014) [48] & $\begin{array}{l}\text { To study sex differences in } \\
\text { clinical characteristics and } \\
\text { outcomes among multi- } \\
\text { ethnic Southeast Asian } \\
\text { patients with hospitalized } \\
\text { heart failure }\end{array}$ & $\begin{array}{l}\text { Hospitals in the Southeast } \\
\text { Asian nation of Singapore, } \\
\text { January 1, } 2008 \text { to } \\
\text { December 31, } 2009\end{array}$ & Prospective & $\begin{array}{l}\text { Length of stay, in } \\
\text { hospital mortality and } \\
\text { rehospitalisation }\end{array}$ \\
\hline Chun (2012) [35] & $\begin{array}{l}\text { Examined a patient cohort } \\
\text { discharged after being newly } \\
\text { hospitalized for HF and } \\
\text { followed them over their } \\
\text { lifetime for all cardiac and } \\
\text { noncardiac hospitalizations } \\
\text { that occurred until death. } \\
\text { Examined patterns of } \\
\text { hospitalization and } \\
\text { recurrent cardiovascular } \\
\text { events and the association } \\
\text { of sex, presence of HFrEF } \\
\text { versus HFpEF, and ischemic } \\
\text { versus nonischemic etiology } \\
\text { on hospitalizations }\end{array}$ & $\begin{array}{l}\text { Hospitals (Ontario, } \\
\text { Canada, April } 1999 \text { to } \\
\text { March 2001) }\end{array}$ & Retrospective & $\begin{array}{l}\text { Recurrent hospitalizations, } \\
\text { cardiovascular events, and } \\
\text { survival }\end{array}$ \\
\hline Eastwood (2014) [33] & $\begin{array}{l}\text { To identify factors associated } \\
\text { with risk of all-cause and } \\
\text { HF-specific readmissions } \\
\text { within } 7 \text { and } 30 \text { days of } \\
\text { discharge }\end{array}$ & $\begin{array}{l}\text { Acute care hospital } \\
\text { in Alberta from } \\
\text { April 1, } 2002 \text { to } \\
\text { March 31, } 2012\end{array}$ & Retrospective & $\begin{array}{l}\text { 7-and 30-day readmission } \\
\text { for all causes, } 7 \text {-and } \\
\text { 30-day readmission for HF }\end{array}$ \\
\hline Gevaert (2014) [47] & $\begin{array}{l}\text { To compare the incidence } \\
\text { and treatment of atrial } \\
\text { fibrillation on admission } \\
\text { between men and women } \\
\text { admitted with acute heart } \\
\text { failure }\end{array}$ & $\begin{array}{l}2 \text { Belgian hospitals, } \\
\text { Nov } 2006 \text { to May } \\
\text { 2012; Patients } \\
\text { included in the } \\
\text { prospective BIO-HF } \\
\text { registry (evaluates } \\
\text { all patients admitted } \\
\text { with the New York } \\
\text { Heart Association } \\
\text { class 3-4) }\end{array}$ & Prospective design & $\begin{array}{l}\text { One-year all-cause mortality } \\
\text { or readmission for HF. } \\
\text { Secondary endpoints were } \\
\text { in-hospital mortality and } \\
\text { restoration of sinus } \\
\text { rhythm at discharge }\end{array}$ \\
\hline Jenghua (2011) [36] & $\begin{array}{l}\text { To determine early } \\
\text { readmission rate after } \\
\text { discharge among patients }\end{array}$ & $\begin{array}{l}\text { Tertiary care hospital } \\
\text { in a large metropolitan } \\
\text { area of Phitsanulok }\end{array}$ & Retrospective & $\begin{array}{l}\text { Rate of readmission } \\
\text { after discharge; } \\
\text { predictors of readmission }\end{array}$ \\
\hline
\end{tabular}
with principal diagnosis of CHF and (2) identify predictors of readmission within 30 days after discharge for this group of patients 
Table 7 Objectives, study population, setting, type of study, and study endpoints as reported in studies with similar rates between males and females. Studies reported by primary author in alphabetical order (Continued)

\begin{tabular}{|c|c|c|c|c|}
\hline $\begin{array}{l}\text { Primary Author } \\
\text { (year) }\end{array}$ & Objectives & $\begin{array}{l}\text { Setting (geographical } \\
\text { location, recruitment period) }\end{array}$ & Study Design & Study Endpoints \\
\hline Lee (2004) [37] & $\begin{array}{l}\text { To evaluate the effect } \\
\text { of gender on the risk of } \\
\text { all-cause rehospitalization } \\
\text { and that specific to heart } \\
\text { failure in a diverse } \\
\text { contemporary cohort of } \\
\text { adults who had been } \\
\text { hospitalized with HF }\end{array}$ & $\begin{array}{l}16 \text { Kaiser Permanente } \\
\text { of Northern California } \\
\text { facilities (July 1, } 1999 \\
\text { to June } 302,000 \text { ) }\end{array}$ & Retrospective cohort & $\begin{array}{l}\text { Any rehospitalisation and } \\
\text { readmission due specifically } \\
\text { to heart failure }\end{array}$ \\
\hline Mullens (2008) [54] & $\begin{array}{l}\text { To investigate whether } \\
\text { there is gender-specific } \\
\text { differences in clinical } \\
\text { presentation, response } \\
\text { to intensive medical } \\
\text { therapy, and outcomes } \\
\text { in patients admitted with } \\
\text { advanced decompensated } \\
\text { heart failure. }\end{array}$ & $\begin{array}{l}\text { Dedicated heart failure } \\
\text { intensive care unit in } \\
\text { clinic (USA, } 2000 \text { to 2006) }\end{array}$ & Retrospective & $\begin{array}{l}\text { All-cause mortality, all-cause } \\
\text { mortality or cardiac } \\
\text { transplantation and first } \\
\text { readmission for heart } \\
\text { failure after discharge }\end{array}$ \\
\hline Nieminen (2008) [53] & $\begin{array}{l}\text { To evaluate the gender } \\
\text { differences in patients } \\
\text { hospitalized for acute } \\
\text { heart failure in the } \\
\text { EuroHeart Failure Survey II }\end{array}$ & $\begin{array}{l}133 \text { Hospitals: university } \\
\text { hospitals } 47,49 \% \\
\text { community or district } \\
\text { hospitals, } 4 \% \text { private } \\
\text { clinics ( } 30 \text { European } \\
\text { countries, October } \\
21 \text { st } 2004 \text { to August } \\
31 \text { st 2005) }\end{array}$ & Prospective & $\begin{array}{l}\text { Gender differences in } \\
\text { prescription of HF medication; } \\
\text { rehospitalizations and } \\
\text { one-year mortality }\end{array}$ \\
\hline Ogah (2015) [44] & $\begin{array}{l}\text { To evaluate the sex } \\
\text { differences in acute } \\
\text { heart failure in sub- } \\
\text { Saharan Africa }\end{array}$ & $\begin{array}{l}12 \text { Cardiology units } \\
\text { ( } 9 \text { sub-Saharan African } \\
\text { countries: Cameroon, } \\
\text { Ethiopia, Kenya, } \\
\text { Mozambique, Nigeria, } \\
\text { Senegal, South Africa, Sudan } \\
\text { and Uganda, July 12,007 } \\
\text { to June } 302,010 \text { ) }\end{array}$ & Prospective & $\begin{array}{l}\text { Length of hospital stay, } \\
\text { mortality rates, and all- } \\
\text { cause re-admission }\end{array}$ \\
\hline Opasich (2004) [41] & $\begin{array}{l}\text { To identify differences } \\
\text { between sexes in the } \\
\text { clinical profile, use of } \\
\text { resources, management } \\
\text { and outcome in a large } \\
\text { population of 'real world' } \\
\text { patients with heart failure }\end{array}$ & $\begin{array}{l}167 \text { Cardiology } \\
\text { (CARD) and } 250 \\
\text { internal medicine } \\
\text { (MED) departments } \\
\text { (Italy, February } 14, \\
2000 \text { to February } \\
25,2000 \text { ) }\end{array}$ & Retrospective & $\begin{array}{l}\text { Number of cardiovascular } \\
\text { procedures and diagnostic, } \\
\text { and pharmacological } \\
\text { therapy, in-hospital mortality }\end{array}$ \\
\hline Otero-Ravina (2009) [56] & $\begin{array}{l}\text { Characterization of current } \\
\text { morbidity and mortality } \\
\text { among heart failure in } \\
\text { Galicia together with their } \\
\text { main determinants }\end{array}$ & $\begin{array}{l}\text { Eight geographical } \\
\text { areas of Galicia, } \\
\text { year } 2006\end{array}$ & Prospective & Survival rates \\
\hline Sajeev (2017) [45] & $\begin{array}{l}\text { Study the demographical } \\
\text { and clinico-pathological } \\
\text { characteristics of patients } \\
\text { presenting with heart } \\
\text { failure and evaluate the } \\
1 \text { year outcomes and to } \\
\text { identify risk predictors if any }\end{array}$ & $\begin{array}{l}\text { A tertiary care centre } \\
\text { (South India, April } \\
\text { 2013-September 2014) }\end{array}$ & Prospective & $\begin{array}{l}\text { Mortality and/or re- } \\
\text { hospitalization due to HF }\end{array}$ \\
\hline Schwarz (2003) [55] & $\begin{array}{l}\text { To evaluate whether } \\
\text { severity of cardiac illness, } \\
\text { cognitive functioning, } \\
\text { and functional health } \\
\text { of older adults with heart } \\
\text { failure (HF) and psychosocial } \\
\text { factors related to caregiving } \\
\text { are predictive of hospital } \\
\text { readmissions for those } \\
\text { with HF }\end{array}$ & $\begin{array}{l}2 \text { Community hospitals } \\
\text { (Ohio, US) }\end{array}$ & Prospective & 3-month re-admission \\
\hline
\end{tabular}


Table 7 Objectives, study population, setting, type of study, and study endpoints as reported in studies with similar rates between males and females. Studies reported by primary author in alphabetical order (Continued)

\begin{tabular}{|c|c|c|c|c|}
\hline $\begin{array}{l}\text { Primary Author } \\
\text { (year) }\end{array}$ & Objectives & $\begin{array}{l}\text { Setting (geographical } \\
\text { location, recruitment period) }\end{array}$ & Study Design & Study Endpoints \\
\hline Sheppard (2005) [34] & $\begin{array}{l}\text { To explore gender } \\
\text { differences in therapy, } \\
\text { resource utilization, and } \\
\text { clinical outcomes in } \\
\text { patients who had CHF }\end{array}$ & $\begin{array}{l}\text { Quebec hospital } \\
\text { summary database } \\
\text { linked to provincial } \\
\text { physician and drug } \\
\text { claims databases, } \\
\text { January } 1998 \text { and } \\
\text { December } 2002\end{array}$ & Retrospective & $\begin{array}{l}\text { Procedure, medical therapy } \\
\text { and re-hospitalizations, } \\
\text { emergency room visits }\end{array}$ \\
\hline Tarantini (2002) [51] & $\begin{array}{l}\text { Evaluate the clinical } \\
\text { characteristics, 1-year } \\
\text { prognosis and therapeutic } \\
\text { approach of heart failure } \\
\text { with a preserved left } \\
\text { ventricular systolic } \\
\text { function in a large } \\
\text { multicenter registry of } \\
\text { patients referred to } \\
\text { specialized heart failure } \\
\text { clinics }\end{array}$ & $\begin{array}{l}133 \text { Centers of the } \\
\text { ANMCO working } \\
\text { group on heart } \\
\text { failure, March1995 } \\
\text { to January } 1999\end{array}$ & Prospective & $\begin{array}{l}\text { Use of cardiovascular } \\
\text { medications, hospitalizations } \\
\text { (all-cause for cardiovascular } \\
\text { events and for worsening CHF }\end{array}$ \\
\hline Zsilinskza (2016) [52] & $\begin{array}{l}\text { Evaluate sex differences } \\
\text { in patients with HFpEF } \\
\text { that presented to the } \\
\text { ED with acute HF, } \\
\text { regarding presentation, } \\
\text { treatments, and outcomes. }\end{array}$ & $\begin{array}{l}83 \text { Hospitals (United } \\
\text { States, January 2004 } \\
\text { to September 2005) }\end{array}$ & Retrospective & $\begin{array}{l}\text { Emergency department } \\
\text { therapies and management, } \\
\text { hospital length of stay, } \\
\text { in-hospital mortality, post- } \\
\text { discharge outcomes }\end{array}$ \\
\hline
\end{tabular}

ANMCO Associazione Nazionale Medici Cardiologi Ospedalieri (National Association of Hospital Doctors Cardiologists), N.R None reported, HFpEF Heart failure preserved ejection faction, ED Emergency department, EF Ejection Faction, AHF Acute heart failure, HF Heart failure, CHF Congestive heart failure, ICD International Statistical Classification of Diseases and related health problems

ventricular function and ischemia and had fewer revascularization procedures.

More studies, in general, reported that women were less likely to receive evidence-based therapies than men. Men were more often prescribed $\beta$-blockers, vasodilators, and antiplatelet agents than women and were administered higher mean doses than women [38]. Women were also less frequently prescribed ACE inhibitors [34]. Chang [48] noted that women were less likely to receive evidence-based therapies upon discharge compared to men. In contrast to the above, Zsilinskza [52] did not note any sex differences in HF therapies, such as administration of diuretics or vasodilators. A potential reason for the similar rates of some drug classes in women is that the higher prevalence of hypertension in women may have overlapping indications for HF. Therefore, increased betablocker therapy in women, for example, may reflect management of hypertension and HF with preserved ejection fraction [34].

\section{Discussion}

Findings from this scoping review confirm that while most of the studies that included sex-based analyses showed no differences in readmission rates following HF hospitalization, several factors still point to the need of targeted sex-based management for at-risk populations. The rise in hospital readmissions is a global concern and is often used as a quality benchmark for health care systems. Hospital readmission is a considerable burden on the individual from a cost perspective and the related treatment costs and hospital resources tax the health system. This review is the first to use a systematic method to describe the literature for assessing readmission rate differences in men and women with an index HF hospitalization.

We have observed that there might be an interplay between sex, timing post-discharge, and readmission rates. Studies in which women were more likely to have higher readmission rates than men tended to have durations of follow-up of less than 12 months. This finding suggests that short-term follow-up, improved self-management and early care following discharge from the hospital may be needed. Reducing readmission rates in women may necessitate consideration of sex-specific roles and supports for women who live alone. In contrast, readmission rates appeared to be higher for men in studies with longer durations of follow-up (> 12 months) [28, 53].

Few studies with a sex and gender sensitive approach have been conducted prospectively. HF readmission is more typical of patients who are men with reduced ejection fraction than women [59]. Two of the retrospective studies which contained information on LVEF $[39,49]$ indicated that the tendency for readmission was higher 
in men as compared to women. When the totality of studies was examined, including those with or without LVEF assessment, more studies indicated a higher readmission rate for men overall.

Sex and gender differences may relate in part to compliance with pharmacological treatments. Analysis of the EuroHeart Failure Survey indicated that compliance with pharmacological therapies differed between men and women. Men may be less compliant to pharmacological treatments, following discharge after an index diagnosis of heart failure. As future next steps, education with good integrated care and follow up conversations with practitioners warrants investigation leading to improved health outcomes and reduced readmission rates among men. The greater use of invasive diagnostic procedures in men may also relate to the observed early differences in outcomes since these procedures may impact early outcomes reflecting the care received during the acute care hospitalization.

A sex specific approach to post-discharge heart failure care may require better access points of care for certain populations. For example, earlier readmission risk in women may suggest that improved postdischarge transitional care, ongoing physician followup in the near-term, home visitation by nurses, and remote patient monitoring could be particularly useful. In men, later readmissions may indicate the need for long-term follow-up, ensurance of medication compliance, and early treatment of conditions such as ischemic HF, which can lead to late readmissions downstream. Further, future studies should report sex-specific readmission and mortality outcomes separately, since the composite outcome of death or readmission may mask informative underlying patterns. Sex-based approaches to pharmacotherapy also warrant greater exploration. For example, it is known that absorption rates and metabolism of digoxin are different between men and women [14]. Thus, serum digoxin should be administered in lower doses to women to avoid toxicity because of these pharmacokinetic differences [60].

\section{Strengths and limitations}

Given the large sample of papers in our database, we focused on sex-sensitive factors which could be part of a global strategy to reduce readmission rates. Our methodology was robust as we included a consultation panel of experts, which is an optional step in the Arksey and O'Malley framework. We also consulted individually with a professional librarian, a cardiologist, and sex and gender experts. We linked the references of relevant studies when a primary research study cited either appendices, supplementary material, or pilot studies or if the same author wrote a dissertation and an abstract in conjunction with a journal article [42, 61, 62].

There are some limitations to our scoping review. A primary objective needed to state evaluations of sex and gender for a study to be included in this scoping review. Secondary or subgroup analyses may not result in conclusive findings without a power calculation for factors related to sex. Further, without a prespecified sample size that powers these secondary analyses, even if findings are positive, may not be clinically relevant. We also found that sex and gender terminology was often confused which could conflate study findings and may not clearly demonstrate how the interrelated nature of these concepts may impact men and women. The time spent in observation units by hospitals and the use of emergency department might be explored in future studies. This scoping review, while providing a description of the research on readmission rates as it relates to sex and gender to date, is limited in its ability to demonstrate trends over time. Finally, the observations of the potential interaction between sex-specific readmission risk and time horizon can only be considered hypothesis generating in this review, and indeed many studies showed no difference. This interaction between sex and time horizon may need to be confirmed in different jurisdictions, accounting for the competing risks of death, before implementing policies directed toward reducing early vs. later-term readmissions.

\section{Conclusion}

Overall, there is an increase in reporting of sex and gender differentiated data; however, we found that in most studies, this was not explicitly stated in the primary objectives. We found more papers reported that men with heart failure had significantly higher readmission rates compared to women with heart failure. The effect of sex on readmission may have been dependent on follow-up duration, with longer follow-up duration favoring higher readmission rates among men. Readmission reduction programs could include targeted educational approaches and conversations with practitioners following discharge about medication compliance and management strategies. In addition, we encourage the use of singular rather than composite measures (i.e. combination of mortality and readmission), the latter having the potential to mask important sex-specific associations. Future studies would be needed to investigate heart failure in relation to readmission rates to examine sex and gender differences and their effects over time. 


\section{Appendix}

Peer Review Assessment

TRANSLATION A. No Revisions

BOOLEAN AND PROXIMITY OPERATORS A. No revisions

SUBJECT HEADINGS b. Revision(s) suggested

There is one missing MeSH. Line \#4 should contain exp. patient readmission. This, however, would be picked up in the PubMed search.

TEXT WORD SEARCHING.A. No revisions

SPELLING, SYNTAX, AND LINE NUMBERS A. No revisions

LIMITS AND FILTERS A. No revisions
OVERALL EVALUATION A. No revisions
Database: Ovid MEDLINE(R) In-Process \& Other Database: Ondex
Non-Indexed Citations and Ovid MEDLINE(R) $<1946$ to Present>

1 exp heart failure/ (106977)

2 *diastolic dysfunction/ or *systolic dysfunction/ or *left ventricular dysfunction/ or *cardiac failure/ or *heart decompensation/ or *cardiac decompensation/ (93738)

31 or 2 (120715)

4 (readmission* or readmit* or rehospital*).af. (28630)

$5 \quad 3$ and 4 (3023)

6 exp sex factors/ or sex based.mp. or sex distribution.mp. or sex characteristics.mp. or sex dimorphism.mp. or gender difference*.mp. or gender based.mp. (352875)

7 (male $\$$ or female $\$$ or men or women or gender or sex).mp. (10901667)

$8 \quad 6$ or 7 (10901667)

95 and $8(2184)$

10 limit 9 to (humans and yr="2002 -Current") (1994)

11 remove duplicates from 10 (1853)

12 exp *heart failure/ (81515)

13 ((diastolic or systolic or ventricular) adj5 dysfunction).ti,ab. (30801)

14 ((cardiac or heart) adj5 decompensation).ti,ab. (1707)

15 ((cardiac or heart) adj5 failure).ti,ab. (151500)

1612 or 13 or 14 or 15 (190157)

17 exp patient readmission/ (12284)

18 (readmission* ${ }^{*}$ or readmit* ${ }^{*}$ or rehospital*).af. (28630)

19 readmission.ti,ab,kf. (13666)

20 readmit*.ti,ab,kf. (5417)

21 rehospital*ti,ab,kf. (4965)

2217 or 18 or 19 or 20 or 21 (28630)

$23 \quad 16$ and $22(4365)$

24 exp sex factors/ (242860)

25 (sex adj5 (characteristic or difference or dimophism or distribution or factor)).ti,ab,kf. (21668)

26 sex.ti. (79842)

27 exp Sex Characteristics/ (49113)

28 (male* adj3 female*).ti,ab. (271988)

29 (men adj3 women).ti,ab. (179256)

30 gender.ti,ab. (250988)

3124 or 25 or 26 or 27 or 28 or 29 or $30(858662)$

$32 \quad 23$ and 31 (333)

33 animals/ not (humans/ and animals/) (4405525)

$34 \quad 32$ not 33 (333)

\section{Acknowledgements}

This paper was presented as an abstract at the European Congress of Cardiology, Paris 2019 [63]

\section{Authors' contributions}

Conception: DSL, AHK, RM, PAR; Design: DSL, AHK, CP, HJR, SM, MEF, LYS, MJS, RM, PAR; Acquisition or analysis of data: DSL, AHK, CP, PCA, HJR, HCW, KT, SM, MEF, MJS, RM, PAR; Interpretation of data: DSL, AHK, CP, PCA, HJR, HCW, KT, SM, MEF, LYS, MJS, RM, PAR; Drafting or substantial revision: DSL, AHK, CP, CF, PCA, HJR, HCW, KT, SM, MEF, LYS, MJS, RM, PAR. The authors have read and approved the final version of the manuscript.

\section{Funding}

This study was supported by a Strategy for Patient-Oriented Research (SPOR) grant from the Ontario SPOR Support Unit (OSSU) and a Foundation Grant from the Canadian Institutes of Health Research (grant \# FDN 148446). Dr. D. Lee is supported by a mid-career investigator award from the Heart and Stroke Foundation and the Ted Rogers Chair in Heart Function Outcomes, a joint Hospital-University Chair of the University Health Network and the University of Toronto. Dr. Austin is supported by a Mid-Career investigator award from the Heart and Stroke Foundation. Dr. Rochon is supported by the RTO/ ERO chair in Geriatric Medicine from the University of Toronto. ICES is supported in part by a grant from the Ontario Ministry of Health and Long Term Care. The opinions, results and conclusions are those of the authors and no endorsement by the Ministry of Health and Long-Term Care or by ICES is intended or should be inferred. The funders had no role in the design of the study and collection, analysis, and interpretation of data an in writing the manuscript.

\section{Availability of data and materials}

See supporting data. All other data are systematically-reviewed from previously published material, and therefore available in the public domain.

\section{Ethics approval and consent to participate}

Not applicable.

\section{Consent for publication}

Not applicable.

\section{Competing interests}

The authors declare that they have no competing interests.

\section{Author details}

'Women's College Research Institute, Toronto, Canada. ${ }^{2}$ Peter Munk Cardiac Centre of University Health Network, Toronto, Canada. ${ }^{3}$ ICES, Toronto, Canada. ${ }^{4}$ Institute for Health Policy, Management and Evaluation, University of Toronto, Toronto, Canada. ${ }^{5}$ Faculty of Medicine, University of Toronto, Toronto, Canada. ${ }^{6}$ Ted Rogers Centre for Heart Research, Toronto, Canada. ${ }^{7}$ Sunnybrook Health Sciences Centre, Toronto, Canada. ${ }^{8}$ North York General Hospital, Department of Family and Community Medicine, University of Toronto, Toronto, Canada. ${ }^{9}$ Sinai Health System, Toronto, Canada. ${ }^{10}$ Division of Cardiac Anesthesiology, University of Ottawa Heart Institute, Ottawa, Canada.

Received: 19 November 2019 Accepted: 9 March 2020

Published online: 14 May 2020

\section{References}

1. Jencks SF, Williams MV, Coleman EA. Rehospitalizations among patients in the Medicare fee-for-service program. N Engl J Med. 2009;360(14):1418-28.

2. Bueno H, Ross JS, Wang Y, Chen J, Vidán MT, Normand SLT, Curtis JP, Drye EE, Lichtman JH, Keenan PS, Kosiborod M, Krumholz HM. Trends in length of stay and short-term outcomes among Medicare patients hospitalized for heart failure 1993-2006. JAMA. 2010;303(21):2141-7.

3. Braga JR, Leong-Poi H, Rac VE, Austin PC, Ross HJ, Lee DS. Trends in the use of cardiac imaging for patients with heart failure in Canada. JAMA Netw Open. 2019;2(8):e198766.

4. Bjorvatn A. Hospital readmission among elderly patients. Eur J Health Econ. 2013;14(5):809-20.

5. Keenan PSNS, Lin Z, et al. An administrative claims measure suitable for profiling hospital performance on the basis of 30-day all-cause readmission rates among patients with heart failure. Circ Cardiovasc Qual Outcomes. 2008;1:29-37. 
6. Ashton CM, Kuykendall DH, Johnson ML, Wray NP, Wu L. The association between the quality of inpatient care and early readmission. Ann Intern Med. 1995;122(6):415-21.

7. Hersh AM, Masoudi FA, Allen LA. Postdischarge environment following heart failure hospitalization: expanding the view of hospital readmission. J Am Heart Assoc. 2013;2(2):e000116.

8. Louis AA, Turner T, Gretton M, Baksh A, Cleland JG. A systematic review of telemonitoring for the management of heart failure. Eur J Heart Fail. 2003; 5(5):583-90

9. Nolte E, Roland M, Guthrie S, Brereton L. Preventing emergency readmissions to hospital: a scoping review. Rand Health Quart. 2012;2(1):10.

10. Protection P, Act AC. Patient protection and affordable care act. Public law. 2010;111(48):759-62

11. Lloyd-Jones DMLM, Leip EP. Lifetime risk for developing congestive heart failure: the Framingham heart study. Circulation. 2002;106:3068-72.

12. Tannebaum CCB, Haworth-Brockman M. Sex and gender considerations in Canadian clinical practice guidelines: a systematic review. CMAJ Open. 2017; 5(1):E66-73.

13. McGregor AJFPW, Marie Chang A, Safdar B, Diercks D. Sex- and genderspecific research priorities for the emergency management of heart failure and acute arrhythmia: proceedings from the 2014 Academic emergency medicine consensus conference cardiovascular research workgroup. Acad Merg Med. 2014;21:1361-9.

14. Eisenberg E, Di Palo KE, Pina IL. Sex differences in heart failure. Clin Cardiol. 2018;41(2):211-6.

15. Jeon Y-H, Kraus SG, Jowsey T, Glasgow NJ. The experience of living with chronic heart failure: a narrative review of qualitative studies. BMC Health Serv Res. 2010;10(1):77.

16. McGregor AJ, Frank Peacock W, Marie Chang A, Safdar B, Diercks D. Sex-and gender-specific research priorities for the emergency Management of Heart Failure and Acute Arrhythmia: proceedings from the 2014 academic emergency medicine consensus conference cardiovascular research workgroup. Acad Emerg Med. 2014;21(12):1361-9.

17. Sun LY, Tu JV, Coutinho T, et al. Sex differences in outcomes of heart failure in an ambulatory, population-based cohort from 2009 to 2013. Can Med Assoc J. 2018;190(28):E848-54.

18. Arksey H, O'Malley L. Scoping studies: towards a methodological framework. Int J Soc Res Methodol. 2005:8(1):19-32.

19. Joanna Briggs Institute Reviewers' Manual. Adelaide: The Joanna Briggs Institute; 2015

20. O'Brien KK, Colquhoun H, Levac D, et al. Advancing scoping study methodology: a web-based survey and consultation of perceptions on terminology, definition and methodological steps. BMC Health Serv Res. 2016:16(1):305.

21. McGowan J, Sampson M, Salzwedel DM, Cogo E, Foerster V, Lefebvre C. PRESS peer review of electronic search strategies: 2015 guideline statement. J Clin Epidemiol. 2016:75:40-6.

22. Bryman ABR. Analyzing qualitative data; 1994. p. 232

23. Cordoba GSL, Woloshin S, Bae H, Gotzsche P. Definition, reporting and interpretation of composite outcomes in clinical trials: systematic review. BMJ. 2010;341:3920.

24. Gahagan JGK, Whynacht A. Sex and gender matter in health research: addressing health inequities in health resaerch reporting. Int J Equity Health 2015;14:12.

25. MacDonald MR, Jhund PS, Petrie MC, et al. Discordant short- and long-term outcomes associated with diabetes in patients with heart failure: importance of age and sex: a population study of 5.1 million people in Scotland. Circ Heart Fail. 2008;1(4):234-41.

26. Arora S, Patel P, Lahewala S, et al. Etiologies, trends, and predictors of 30day readmission in patients with heart failure. Am J Cardiol. 2017;119(5): 760-9.

27. Omersa D, Farkas J, Erzen I, Lainscak M. National trends in heart failure hospitalization rates in Slovenia 2004-2012. Eur J Heart Fail. 2016;18(11): 1321-8

28. Howlett JG, Mann OE, Baillie R, et al. Heart failure clinics are associated with clinical benefit in both tertiary and community care settings: data from the improving cardiovascular outcomes in Nova Scotia (ICONS) registry. Can J Cardiol. 2009;25(9):e306-11.

29. Madigan EA, Gordon NH, Fortinsky RH, Koroukian SM, Pina I, Riggs JS. Rehospitalization in a national population of home health care patients with heart failure. Health Serv Res. 2012;47(6):2316-38.
30. Robertson J, McElduff P, Pearson SA, Henry DA, Inder KJ, Attia JR. The health services burden of heart failure: an analysis using linked population health data-sets. BMC Health Serv Res. 2012;12:103.

31. Blackledge HM, Newton J, Squire IB. Prognosis for south Asian and white patients newly admitted to hospital with heart failure in the United Kingdom: historical cohort study. BMJ. 2003;327(7414):526-31

32. Bradford C, Shah BM, Shane P, Wachi N, Sahota K. Patient and clinical characteristics that heighten risk for heart failure readmission. Res Soc Adm Pharm. 2016;13(6):1070-81.

33. Eastwood CA, Howlett JG, King-Shier KM, McAlister FA, Ezekowitz JA, Quan $\mathrm{H}$. Determinants of early readmission after hospitalization for heart failure. Can J Cardiol. 2014;30(6):612-8.

34. Sheppard R, Behlouli H, Richard H, Pilote L. Effect of gender on treatment, resource utilization, and outcomes in congestive heart failure in Quebec, Canada. Am J Cardiol. 2005:95(8):955-9.

35. Chun S, Tu JV, Wijeysundera HC, et al. Lifetime analysis of hospitalizations and survival of patients newly admitted with heart failure. Circ Heart Fail. 2012;5(4):414-21.

36. Jenghua $\mathrm{K}$, Jedsadayanmata $\mathrm{A}$. Rate and predictors of early readmission among Thai patients with heart failure. J Med Assoc Thail. 2011;94(7):782-8.

37. Lee WY, Capra AM, Jensvold NG, et al. Gender and risk of adverse outcomes in heart failure. Am J Cardiol. 2004;94(9):1147-52.

38. Jimenez-Navarro MF, Ramirez-Marrero MA, Anguita-Sanchez M, Castillo JC, Investigators B. Influence of gender on long-term prognosis of patients with chronic heart failure seen in heart failure clinics. Clin Cardiol. 2010;33(3):E13-8.

39. Goncalves A, Azevedo A, Almeida R, et al. Left ventricular systolic function in the prognosis of patients hospitalized due to worsening heart failure. Rev Port Cardiol. 2008:27(2):177-82

40. Ogah OS, Stewart S, Falase AO, et al. Predictors of rehospitalization in patients admitted with heart failure in Abeokuta, Nigeria: data from the Abeokuta heart failure registry. J Card Fail. 2014;20(11):833-40.

41. Opasich C, De Feo S, Ambrosio GA, et al. The 'real' woman with heart failure. Impact of sex on current in-hospital management of heart failure by cardiologists and internists. Eur J Heart Fail. 2004;6(6):769-79.

42. Howie-Esquivel J, Dracup K. Effect of gender, ethnicity, pulmonary disease, and symptom stability on rehospitalization in patients with heart failure. Am J Cardiol. 2007;100(7):1139-44.

43. Sato T, Yamauchi H, Kanno $Y$, et al. Comparisons of prognostic factors between young and elderly patients with chronic heart failure. Geriatr Gerontol Int. 2015;15(4):435-42.

44. Ogah OS, Davison BA, Sliwa K, et al. Gender differences in clinical characteristics and outcome of acute heart failure in sub-Saharan Africa: results of the THESUS-HF study. Clin Res Cardiol. 2015;104(6):481-90.

45. Sajeev CG, Rajan Nair S, George B, Rajesh GN, Krishnan MN. Demographical and clinicopathological characteristics in heart failure and outcome predictors: a prospective, observational study. ESC Heart Fail 2017; 4(1):16-22.

46. Vader JM, LaRue SJ, Stevens SR, et al. Timing and causes of readmission after acute heart failure hospitalization-insights from the heart failure network trials. J Card Fail. 2016:22(11):875-83.

47. Gevaert SA, de Bacquer D, Willems AM, et al. Gender differences in the management and outcome of atrial fibrillation complicating acute heart failure. J Card Fail 2014; 20(6):431-7.

48. Chang P, Chia SY, Sim LL, et al. Impact of sex on clinical characteristics and in-hospital outcomes in a multi-ethnic southeast Asian population of patients hospitalized for acute heart failure. ASEAN Heart J. 2014;22(1):8

49. Alla F, Al-Hindi AY, Lee CR, Schwartz TA, Patterson JH, Adams KF Jr. Relation of sex to morbidity and mortality in patients with heart failure and reduced or preserved left ventricular ejection fraction. Am Heart J. 2007;153(6):1074-80.

50. leva F, Jackson CH, Sharples LD. Multi-state modelling of repeated hospitalisation and death in patients with heart failure: the use of large administrative databases in clinical epidemiology. Stat Methods Med Res. 2015;26(3):1350-72.

51. Tarantini $L$, Faggiano $P$, Senni $M$, et al. Clinical features and prognosis associated with a preserved left ventricular systolic function in a large cohort of congestive heart failure outpatients managed by cardiologists. Data from the Italian Network on Congestive Heart Failure. Ital Heart J. 2002;3(11):656-64.

52. Zsilinszka R, Shrader P, DeVore AD, et al. Sex differences in the management and outcomes of heart failure with preserved ejection fraction in patients presenting to the emergency department with acute heart failure. J Card Fail. 2016;22(10):781-8. 
53. Nieminen MS, Harjola VP, Hochadel $M$, et al. Gender related differences in patients presenting with acute heart failure. Results from EuroHeart failure survey II. Eur J Heart Fail. 2008;10(2):140-8.

54. Mullens W, Abrahams Z, Sokos G, et al. Gender differences in patients admitted with advanced decompensated heart failure. Am J Cardiol. 2008; 102(4):454-8.

55. Schwarz KA, Elman CS. Identification of factors predictive of hospital readmissions for patients with heart failure. Heart Lung. 2003;32(2):88-99.

56. Otero-Ravina F, Grigorian-Shamagian L, Fransi-Galiana L, et al. Morbidity and mortality among heart failure patients in Galicia, N.W. Spain: the GALICAP Study. Int J Cardiol. 2009;136(1):56-63.

57. Ahmed A, Bourge RC, Fonarow GC, et al. Digoxin Use and Lower 30-day Allcause Readmission for Medicare Beneficiaries Hospitalized for Heart Failure. Am J Med. 2014;127(1):61-70.

58. Islam T, O'Connell B, Lakhan P. Hospital readmission among older adults with congestive heart failure. Aust Health Rev. 2013;37(3):362-8.

59. Caughey M, Stearns S, Shah A, et al. Readmissions for patients discharged with acute decompensated heart failure and reduced versus preserved ejection fraction: the atherosclerosis risk in communities study. J Am Coll Cardiol. 2017;69(11 Supplement):775.

60. Rathore SSWY, Krumholz HM. Sex-based differences in the effect of digoxin for the treatment of heart failure. N Engl J Med. 2002;347:1403-11.

61. Esquivel JH. Gender and ethnicity confer greatest risk for Rehospitalization in heart failure patients. Am Heart Assoc. 2006;114(suppl 18):II-517.

62. Howie JN. Predictors for Rehospitalization in hospitalized heart failure patients. Thesis; 2005.

63. Hoang-Kim A, Parpia C, Freitas C, et al. Men with heart failure have higher readmission rates: a closer review of sex and gender based analyses. Eur Heart J. 2019;40(suppl 1):P3518.

\section{Publisher's Note}

Springer Nature remains neutral with regard to jurisdictional claims in published maps and institutional affiliations.

Ready to submit your research? Choose BMC and benefit from:

- fast, convenient online submission

- thorough peer review by experienced researchers in your field

- rapid publication on acceptance

- support for research data, including large and complex data types

- gold Open Access which fosters wider collaboration and increased citations

- maximum visibility for your research: over $100 \mathrm{M}$ website views per year

At $\mathrm{BMC}$, research is always in progress.

Learn more biomedcentral.com/submissions 